\title{
Restoring Ecological Functions Using Agroforestry Systems in Riparian Forests
}

\author{
Lucas Bertacini Viégas $^{1}{ }^{\mathbb{D}}$, José Mauro Santana da Silva ${ }^{2}$ (D), \\ Marcio de Camargo Pala² (D), Fatima Conceição Márquez Piña-Rodrigues² (D)
}

${ }^{1}$ Universidade Estadual Paulista Júlio de Mesquita Filho (Unesp), Botucatu, SP, Brasil

${ }^{2}$ Universidade Federal de São Carlos (UFSCar), Sorocaba, SP, Brasil

\begin{abstract}
Agroforestry systems and restoration models were compared with native forests by examining the restoration of ecological processes that generate stability, resilience and reliability. The stability assessment was obtained using indicators of diversity, structure and functionality. Indicators of soil protection and nutrient cycling were also used to estimate the resilience. The reliability was assessed by management and protection indicators, anthropic impact and canopy (percentage of light). Agroforestry systems did not promote the restoration of ecological functions due mainly to structural factors than management. The production of biomass and carbon storage were higher in the agroforestry system considering the association of trees with short cycle crops $\left(3.2 \mathrm{tha}^{-1} \mathrm{yr}^{-1} ; 39.81 \mathrm{t} \mathrm{Cha}^{-1}\right)$ than trees with green manure system $\left(2.4 \mathrm{ha}^{-1} \mathrm{yr}^{-1} ; 34.09 \mathrm{t} \mathrm{C} \mathrm{ha}^{-1}\right)$. After 36 months, the restoration methods and agroforestry systems did not provide resilience and stability for the riparian forests protection.
\end{abstract}

Keywords: ecological indicators, adaptive management, carbon sequestration. 


\section{INTRODUCTION AND OBJECTIVES}

Agroforestry systems have been one of the alternatives for ecological restoration because reconcile environmental recovery and the diversified production (Oliveira et al., 2016). These systems gained prominence in Brazil with the publication of the National Plan for the Recovery of Native Vegetation, Decree no. 8.972 (Brasil, 2017) which imposes the recomposition of 12 million hectares in 20 years, being part of those with agroforestry systems (AFS) established in legally protected areas. The planting of AFS in legally protected riparian areas (APPs) is regulated by legal requirements (Brasil, 2011) that allowed its adoption in small properties until the fifth-year post-planting. In São Paulo, the Resolution SMA no. 44 of June 30, 2008 (São Paulo, 2008b) defined the criteria for using AFS in APP of small properties. Also, the Resolution SMA no. 32 of April 3, 2014 (Art. 11, subsection IV, $\$ 4$ and Art. 12) allowed the use of this system for the restoration of up to $50 \%$ of the riparian area (São Paulo, 2014). Although AFSs can promote environmental sustainability (Seoane et al., 2014), it is still necessary to assess and monitor their ability to restore the ecological functions previously performed by forest cover. In general, these ecological functions are associated with the structure and the forest's composition (Srivastava \& Vellend, 2005), and they contribute to the system's diversity, stability and resilience (Astier et al., 2011). However, other functions related to ecological processes such as productivity, biomass and carbon accumulation (Sharrow \& Ismail, 2004); biological nitrogen fixation (Piotto, 2008); nutrient cycling and presence of functional groups species (Lomov et al., 2006) can also be considered as indicators of the restoration effectiveness (Tongway \& Hindley, 2004). The monitoring of ecological functions such as its fixation potential and the $\mathrm{CO}_{2}$ reducing effectiveness levels can work as an indicator to evaluate the restoration (Melo \& Durigan, 2006) being capable of analyzing the ecosystems functioning, which allows the comparison of different systems and their fragility degree (Deponti et al., 2002). However, for the AFSs differences, among the models used, their unique composition, management forms, density and arrangement of plants make it difficult to extrapolate and compare one system to another (Nair, 2012).

Among the monitoring environmental methods for sustainability, the Mesmis (Indicator-based Framework for Evaluation of Natural Resource Management Systems) (López-Ridaura et al., 2002) stands out for its flexibility to compare different systems over time (Theodoro et al., 2011). It is based on stability indicators (system's ability to maintain steady), resilience (ability to return to the equilibrium state or maintain its productive potential, even after disturbance) and reliability of systems (ability to keep productivity at the levels close to its long-term equilibrium) (López-Ridaura et al., 2002). However, its effectiveness depends on the application on several scenarios in order to generate reference data (Astier et al., 2011). In this context, the objective of this work was to evaluate the ecological restoration processes in different agroforestry models systems in riparian areas.

\section{MATERIALS AND METHODS}

The studies were carried out in five areas located at the Sorocaba and middle Tietê river, São Paulo. The local climate is defined as Cwa (high-altitude tropical), with averages of temperature $22{ }^{\circ} \mathrm{C}$ and, annual rainfall $1.206 \mathrm{~mm}$ (Fundespa, 2009; Itesp, 2007). Based on the Mesmis method (López-Ridaura et al., 2002), the following areas were used as reference: (a) fragment of a conserved dry forest area (AR1), and (b) a restoration area (AR2). They were compared with another restoration area (R) and two agroforestry systems ( $\mathrm{F}$ and $\mathrm{H}$ ) (Table 1), located in a riparian area of the same rural settlement of $17 \mathrm{ha}$. In AR1 and AR2, floristic studies were carried out in 15 random plots of $100 \mathrm{~m}^{2}$, with subplots of $10 \mathrm{~m} \times 10 \mathrm{~m}$. In the other areas ( $\mathrm{R}, \mathrm{F}$ and $\mathrm{H})$, five permanent plots of $20 \mathrm{~m} \times 20 \mathrm{~m}$ were divided into $10 \mathrm{~m} \times 10 \mathrm{~m}$ subplots where the indicators were applied. Monitoring was accomplished in August 2012, in the fourth (H and F) and fifth (R) postplanting year with 23 indicators based on expected scenarios and theoretical references (Table 2). The indicators were transformed into parameters and used to elaborate radar charts, which allowed to compare the areas within the same evaluation unit as proposed by Ricarte et al. (2006).

For the species diversity and composition analysis, the richness, diversity and equitability indices were determined according to Magurran (2004). Total height and diameter at breast height (DBH) data were obtained for plants with $\mathrm{DBH} \geq 5 \mathrm{~cm}$ and over $1.30 \mathrm{~m}$ height, observing the bifurcations presence and position and the epiphytes occurrence. The percentages of soil covering with herbaceous species, invasive grasses, mulch and litter were estimated at three random points in each subplot 
using a $0.5 \mathrm{~m} \times 0.5 \mathrm{~m}$ frame subdivided into quadrants of $0.25 \mathrm{~m} \times 0,25 \mathrm{~m}$. At each point, the litter height was measured and samples $(n=5)$ were collected. In the laboratory, the litter samples were separated into the fractions of leaves, branches, reproductive material and remains, and then dried in an oven at $65^{\circ} \mathrm{C}$ for $24 \mathrm{~h}$ to get the biomass quantification $\left(\mathrm{kg} \mathrm{ha}^{-1}\right)$. The canopy closure was estimated by: (a) incident light (\%), obtained with the use of a flat reflector subdivided into 40 squares of $4 \mathrm{~cm}^{2}$; it was kept at $50 \mathrm{~cm}$ from the observer, at the height of the ground and $1 \mathrm{~m}$ from it in the center of each subplot sample, obtaining the average number of squares with more than $50 \%$ covered by the crown projections in each direction (N, S, E and W). (b) Canopy cover, obtained in each permanent plot by tracing a $25 \mathrm{~m}$ diagonal line, collecting the data from the crown projections, according to Melo et al. (2007). The difference between the areas concerning the descriptors of diversity and species composition was evaluated by the non-parametric Kruskal-Wallis test and, for height and $\mathrm{DBH}$, by the chi-square test. The similarity between the areas was determined by the cluster analysis using the Euclidean distance method calculated by the original data arranged in the $5 \times 23$ matrix (areas $\times$ indicators) using the free program Past. 3.14 (Hammer et al., 2001). Estimation of carbon fixation was obtained for all trees with $\mathrm{DBH} \geq 5 \mathrm{~cm}$. The biomass (Y) above the soil was calculated with the allometric equation developed for tropical forests (Brown, 1997) (Equation 1) and the $\mathrm{CO}_{2}$ stock estimates were based on the factor 0.5 (MacDicken, 1997).

\section{$\mathrm{Y}=\exp [-1.996+2.32 \times \ln (\mathrm{DBH})]$}

Y: above ground biomass; exp: exponential; ln: Napierian logarithm; DBH: diameter at breast height.

Table 1. Characterization of the reference area located in Sorocaba (AR1), the restoration models located in Itu, SP (AR2), Porto Feliz, SP (R) and agroforestry systems (F and H) located in legally protected riparian areas (APP) in Porto Feliz, SP.

\begin{tabular}{|c|c|c|c|}
\hline Code & $\begin{array}{c}\text { Function/ } \\
\text { Restoration } \\
\text { model }\end{array}$ & Characterization & Dominant forest species \\
\hline AR1 & $\begin{array}{l}\text { Conservation } \\
\text { reference area }\end{array}$ & $\begin{array}{l}\text { Set of fragments }(\mathrm{F}) \text { at } 16.6 \mathrm{~h} \text {. Being: F1 }-4.5 \mathrm{ha} \text {, } \\
\text { F2 - } 1.68 \text { ha, F3 }-4.75 \text { ha, F } 4-4.16 \text { ha and } \\
\text { F5 - } 1.54 \text { ha, with pastures predominance in its } \\
\text { surroundings, located in Sorocaba-SP }\left(23^{\circ} 34^{\prime \prime} 41.00^{\prime \prime} \mathrm{S}\right. \\
\left.\text { e } 47^{\circ} 31^{\prime} 04.89^{\prime \prime} \mathrm{O}\right) .\end{array}$ & $\begin{array}{l}\text { Lithraea molleoides (Vell.) Engel, Copaifera langsdorffii Desf, } \\
\text { Casearia sylvestris Sw, Cryptocarya moschata Ness; C., Protium } \\
\text { heptaphyllum (Aubl.) M., Pera glabrata (Schott) Poepp., Gochnatia } \\
\text { polymorpha (Less.) Cambess } \\
\text { Persea pyrifolia Ness, Tapirira guianensis Aubl }\end{array}$ \\
\hline AR2 & $\begin{array}{l}\text { Forest } \\
\text { Restoration } \\
\text { reference area }\end{array}$ & $\begin{array}{l}\text { Restoration area ( } 127.98 \text { ha) in } 2008 \text { with different } \\
\text { reforestation models, applying regular silvicultural } \\
\text { practices according to SMA no. } 08 / 2008 \text { (São Paulo, } \\
\text { 2008a). It was used a 6-ha study unit with } 3 \mathrm{~m} \times 2 \mathrm{~m} \\
\text { spacing, by the diversity and filling model (Rodrigues } \\
\text { et al., 2009), at the planting of } 800 \text { seedlings ha- } 1 \text { and } \\
\text { enrichment with } 200 \text { seedlings ha- } 1 \text {. Location: Itu, SP } \\
\left(23^{\circ} 20^{\prime} \mathrm{S} \text { and } 47^{\circ} 20^{\prime} \text { W). Age: } 48 \text { months. }\right.\end{array}$ & $\begin{array}{l}\text { Aloysia virgata (Ruiz;Pav.) Juss, Aspidosperma polyneuron } \\
\text { Muell. Arg., Bauhinia longifólia D. Dietr, Casearia } \\
\text { sylvestris Sw., Schinus terebinthifolius Raddi, Cytharexyllum } \\
\text { myrianthum Cham, Guazuma ulmifolia Lam., Luehea } \\
\text { divaricata Mart., Machaerium nyctitans (Vell.) Benth., } \\
\text { Cedrella fissilisVell., Copaifera langsdorffii Desf., Eugenia } \\
\text { uniflora L., Inga edulis Mart. }\end{array}$ \\
\hline $\mathrm{R}$ & $\begin{array}{l}\text { Forest } \\
\text { Restoration } \\
\text { model in APP }\end{array}$ & $\begin{array}{l}\text { APP Reforested pasture area ( } 8.0 \text { ha) using the filling } \\
\text { and diversity model (Rodrigues et al., 2009) with } \\
\text { spacing } 3 \mathrm{~m} \times 2 \mathrm{~m} \text {, planted in } 2007 \text {. In this area, } \\
\text { silvicultural practices were applied irregularly, not } \\
\text { following SMA Resolution } 08 / 2008 \text {. Location: Porto } \\
\left.\text { Feliz, SP ( } 23^{\circ} 13^{\prime} 02^{\prime} \text { S, } 47^{\circ} 31^{\prime} 35^{\prime \prime} \mathrm{O}\right) \text {. } \\
\text { Age: } 60 \text { months. }\end{array}$ & $\begin{array}{l}\text { Anadenanthera colubrina (Vell.) Brenan, Campomanesia } \\
\text { lineatifolia Ruiz; Pav., Chorisia speciosa A.St.-Hil., Citharexylum } \\
\text { myrianthum Cham., Croton floribundus Spreng., Croton } \\
\text { urucurana Baillon., Enterolobium contortisiliquum (Vell.) } \\
\text { Morong., Guazuma ulmifolia Lam., Inga vera Willd., Jacaranda } \\
\text { decurrens Cham., Myrcia bella Cambess., Blake }\end{array}$ \\
\hline $\mathrm{F}$ & $\begin{array}{l}\text { Restoration } \\
\text { model with } \\
\text { agroforestry } \\
\text { system (AFS). } \\
\text { Association } \\
\text { of native } \\
\text { forest species } \\
\text { and green } \\
\text { manure }\end{array}$ & $\begin{array}{l}\text { APP Reforested pasture area ( } 3.7 \text { ha) by the filling } \\
\text { and diversity model (Rodrigues et al., 2009), planted } \\
\text { in } 2008 \text {. Native forest species and short cycle crop } \\
\text { species association unit, with soil restoration function. } \\
\text { In this area, the effective management of biomass } \\
\text { incorporation in the soil (pigeon pea - Cajanus cajan } \\
\text { (L.) Millsp) was not carried out. Location: Porto Feliz, } \\
\text { SP ( } 23^{\circ} 13^{\prime} 02^{\prime} \text { S, } 47^{\circ} 31^{\prime} 35^{\prime \prime} \text { O). Age: } 48 \text { months. }\end{array}$ & $\begin{array}{l}\text { Anadenanthera colubrina (Vell.) Brenan, Caesalpinia férrea Mart. } \\
\text { ex Tul., Citharexylum myrianthum Cham., Croton urucurana } \\
\text { Baillon,Enterolobium contortisiliquum (Vell.) Morong. } \\
\text { Erytrhrina dominguezii Hassl., Handroanthus heptaphyllus (Vell.) } \\
\text { Mattos, Inga laurina (Sw.) Willd., Jacaranda micrantha Cham., } \\
\text { Luehea divaricata Mart., Luehea grandiflora Mart. } \\
\text { Muntigia calabura L., Peltophorium dubium (Spreng) Taub., } \\
\text { Senegalia polyphylla (DC) Britton; Rose }\end{array}$ \\
\hline $\mathrm{H}$ & $\begin{array}{l}\text { Restoration } \\
\text { model with } \\
\text { agroforestry } \\
\text { system (AFS). } \\
\text { Association } \\
\text { of native } \\
\text { forest species } \\
\text { and short } \\
\text { cycle crops }\end{array}$ & 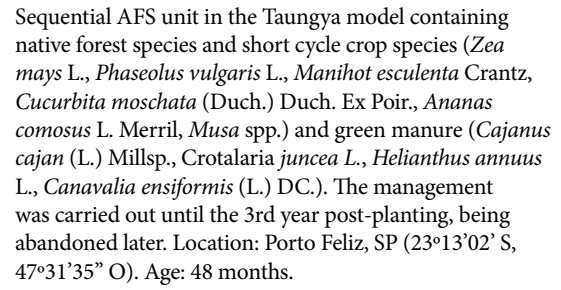 & $\begin{array}{l}\text { Albizia niopoides (Bentham) Burkart, Caesalpinia ferrea } \\
\text { Mart. ex Tul., Chorisia speciosa A.St.-Hil. } \\
\text { Croton floribundus Spreng., Croton urucurana } \\
\text { Baillon,Enterolobium contortisiliquum (Vell.) Morong., } \\
\text { Erithrina crista galli L., Eugenia monosperma Vell., Inga } \\
\text { vera Willd., Jacaranda micrantha Cham., Lafoensia pacari } \\
\text { A.St.-Hil., Peltophorium dubium (Spreng.) Taub., Senna } \\
\text { macranthera (DC. ex Collad.) H.S. Irwin; Barneby, Triplaris } \\
\text { americana L. }\end{array}$ \\
\hline
\end{tabular}


Table 2. Set of ecological sustainability attributes with their descriptors and ecological indicators used for the functionality comparison of the study areas. Based on the Mesmis method (López-Ridaura et al., 2002).

\begin{tabular}{|c|c|c|c|c|}
\hline Descriptor & Indicator & Description & Scenario & Parameters \\
\hline \multicolumn{5}{|c|}{ Stability and resilience } \\
\hline \multicolumn{5}{|c|}{ Community structure } \\
\hline \multirow{9}{*}{ 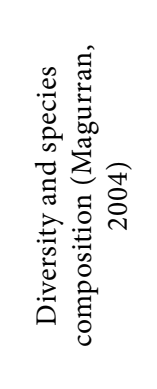 } & \multirow{3}{*}{ Diversity } & \multirow{3}{*}{$\begin{array}{l}\text { Shannon Index } \\
\left(\mathrm{H}^{\prime}\right)\end{array}$} & Similar to the AR1 reference area & $\mathrm{H}^{\prime}>2.0=3$ (high) \\
\hline & & & $\mathrm{H}^{\prime}=1.671$ nat.ind $^{-1}$ & $1.0<\mathrm{H}^{\prime}<1.9=2$ (mean) \\
\hline & & & & $\mathrm{H}^{\prime}<0.9=1$ (low) \\
\hline & \multirow{3}{*}{ Equitability } & \multirow{3}{*}{ Pielou Index (J') } & Similar to the AR1 reference area & $J^{\prime} \geq 1=3$ \\
\hline & & & $J^{\prime}=1.09$ & $0.5<\mathrm{J}^{\prime}<0.9=2$ \\
\hline & & & & $\mathrm{J}^{\prime}<0.5=1$ \\
\hline & \multirow{3}{*}{$\begin{array}{l}\text { Species } \\
\text { richness }\end{array}$} & \multirow{3}{*}{$\begin{array}{l}\text { Number of tree } \\
\text { species (SR) }\end{array}$} & $\begin{array}{c}\text { Presence of } 50 \% \text { of the species } \\
\text { number in the reference area (AR1) }\end{array}$ & $\mathrm{SR}>30=3$ \\
\hline & & & $S=75$ & $10<\mathrm{SR}<30=2$ \\
\hline & & & & $\mathrm{SR}<10=1$ \\
\hline \multirow{17}{*}{ 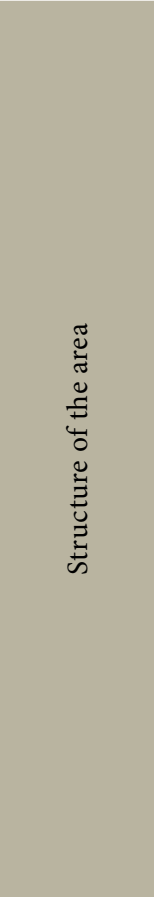 } & \multirow{3}{*}{ Height (m) } & \multirow{3}{*}{$\begin{array}{l}\text { Average height } \\
\text { increments } \\
\text { (IMA) }\end{array}$} & \multirow{3}{*}{$\begin{array}{l}\text { Average increase in the species } \\
\text { height with confidence interval } \\
\text { between } 0.04 \mathrm{~m} \text { to } 0.17 \mathrm{~m} \text { month }{ }^{-1} \text { to } \\
15 \text { months of age }\end{array}$} & IMA $>0,17 \mathrm{~m} \mathrm{month}^{-1}=3$ \\
\hline & & & & $\begin{array}{c}0.04 \mathrm{~m} / \text { month }<\text { IAM }<0.17 \\
\mathrm{~m} \mathrm{month}^{-1}=2\end{array}$ \\
\hline & & & & $\mathrm{IMA}<0.04 \mathrm{~m} \mathrm{month}^{-1}=1$ \\
\hline & \multirow{3}{*}{$\mathrm{DBH}(\mathrm{cm})$} & \multirow{3}{*}{$\begin{array}{l}\text { Average diameter } \\
\text { increment }(\mathrm{ADI})\end{array}$} & \multirow{3}{*}{$\begin{array}{l}\text { Mean increase in diameter (IMD) } \\
\text { with a confidence interval of } 0.20 \mathrm{~cm} \\
\text { to } 0.27 \mathrm{~cm}^{-} \text {per month } \text { m }^{-1} \text { to } 15 \text { months } \\
\text { in restoration plantations }\end{array}$} & $\mathrm{ADI}>0.27 \mathrm{~cm}-1=3$ \\
\hline & & & & $\begin{array}{l}0.20 \mathrm{~cm} \text { month }-1<\text { IMD } \\
<0.27 \mathrm{~cm} \text { month }-1=2\end{array}$ \\
\hline & & & & ADI $<0.20 \mathrm{~cm}$ month $-1=1$ \\
\hline & \multirow{3}{*}{$\begin{array}{l}\text { Bifurcation } \\
\quad \text { (no.) }\end{array}$} & \multirow{5}{*}{$\begin{array}{l}\text { Reflect excessive } \\
\text { light, delay in } \\
\text { establishing } \\
\text { competition } \\
\text { or inadequate } \\
\text { silvicultural } \\
\text { practice }\end{array}$} & $\begin{array}{l}\text { Values compatible with those found } \\
\text { in the reference area (AR1) }\end{array}$ & No. bifurcations $<\mathrm{AR}=3$ \\
\hline & & & $\begin{array}{l}\text { Number of bifurcated individuals }= \\
2.3 \pm 0.35\end{array}$ & No. bifurcations $=\mathrm{AR}=2$ \\
\hline & & & & No. bifurcations $>A R=1$ \\
\hline & \multirow{2}{*}{$\begin{array}{l}\text { Bifurcation } \\
\text { position }\end{array}$} & & Similar to that obtained in AR1 & $\mathrm{UT}<24.3 \%=3$ \\
\hline & & & $\begin{array}{l}\text { In the upper thirds (UT) from zero } \\
\text { to } 24.3 \% \text { of the individuals sampled }\end{array}$ & $\mathrm{UT}>24.3 \%=1$ \\
\hline & \multirow{3}{*}{ No. of strata } & \multirow{3}{*}{$\begin{array}{c}\text { Forest } \\
\text { stratification }\end{array}$} & \multirow{3}{*}{$\begin{array}{l}\text { Presence in the three vegetation } \\
\text { strata formed by the upper canopy } \\
\text { (height greater than } 12 \mathrm{~m} \text { ), medium } \\
\text { stratum (from } 5 \mathrm{~m} \text { to } 12 \mathrm{~m} \text { ) and } \\
\text { lower }(<5 \mathrm{~m} \text { ) (Brasil, 1994) }\end{array}$} & Three strata $=3$ \\
\hline & & & & Two strata $=2$ \\
\hline & & & & A stratum $=1$ \\
\hline & & & Functional diversity & \\
\hline & Presence of & Forest structure & Sources of resources and shelter for & Present $=3$ \\
\hline & epiphytes & restoration & fauna, water cycling and nutrients & Absent $=0$ \\
\hline \multirow{7}{*}{ 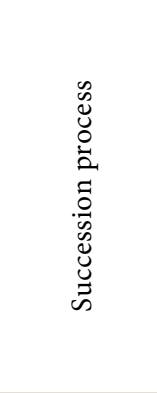 } & \multirow{3}{*}{$\begin{array}{l}\% \text { of } \\
\text { species per } \\
\text { ecological } \\
\text { group }\end{array}$} & \multirow{3}{*}{$\begin{array}{l}\text { Number of } \\
\text { species by } \\
\text { ecological } \\
\text { groups used in } \\
\text { restorations }\end{array}$} & & $\mathrm{NP}>60 \%=3$ \\
\hline & & & & $40 \%<\mathrm{NP}<60 \%=2$ \\
\hline & & & $\begin{array}{l}\text { 08/2008). NP = non-pioneer; } \\
\mathrm{P}=\text { pioneer }\end{array}$ & $\mathrm{NP}<40 \%=1$ \\
\hline & & & Presence of species with ecological & $\mathrm{f}_{\text {eco }} \geq 4=3$ \\
\hline & Ecological & Ecological & functions $\left(\mathrm{f}_{\text {eco }}\right)$ of nitrogen fixation & $1>\mathrm{f}_{\text {eco }}<4=2$ \\
\hline & functions of & functions of the & $\begin{array}{l}\text { by microorganisms, biomass } \\
\text { contribution (deciduous species) }\end{array}$ & $\mathrm{f}_{\text {eco }} \leq 1=1$ \\
\hline & & species employed & $\begin{array}{l}\text { fauna attraction (zoocoric species) } \\
\text { and shading (broad crowns) }\end{array}$ & None $=0$ \\
\hline & Height of & Height of leaf & $\begin{array}{l}\text { Similar to that obtained in AR1, at } \\
\text { the same time }\end{array}$ & $>\mathrm{AR} 1=3$ \\
\hline 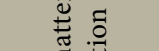 & litter & $\begin{array}{l}\text { deposition } \\
\text { stratum }\end{array}$ & $(\mathrm{AR} 1=5.46 \pm 0.2 \mathrm{~cm})$ & FALSE \\
\hline בี & & & & $<\mathrm{AR} 1=1$ \\
\hline$\stackrel{\Xi}{\Xi}$ & & & & $>75 \%=3$ \\
\hline क & $\begin{array}{l}\% \text { or area } \\
\text { covered by }\end{array}$ & $\begin{array}{l}\text { Soll covering } \\
\text { with organic }\end{array}$ & Values similar to the reference area & $50 \%-75 \%=2$ \\
\hline & & matter. & $(\mathrm{AR} 1)$ & $25 \%-50 \%=1$ \\
\hline & & & & $1-25 \%=0$ \\
\hline
\end{tabular}


Table 2. Continued...

\begin{tabular}{|c|c|c|c|c|}
\hline Descriptor & Indicator & Description & Scenario & Parameters \\
\hline \multicolumn{5}{|c|}{ Stability and resilience } \\
\hline \multicolumn{5}{|c|}{ Community structure } \\
\hline \multicolumn{5}{|c|}{ Management and conservation } \\
\hline \multirow{4}{*}{ 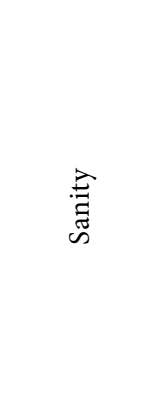 } & \multirow[b]{2}{*}{$\begin{array}{l}\text { Presence of } \\
\text { termites and } \\
\text { ants }\end{array}$} & \multirow[b]{2}{*}{$\begin{array}{l}\text { Ants and termites } \\
\text { nests }\end{array}$} & \multirow{2}{*}{$\begin{array}{l}\text { Absence of ants and termites } \\
\text { is expected, indicating the } \\
\text { implementation of appropriate } \\
\text { cultural practices and control }\end{array}$} & Absent $=3$ \\
\hline & & & & Present $=1$ \\
\hline & \multirow[b]{2}{*}{$\begin{array}{l}\text { Presence of } \\
\text { lianas and } \\
\text { vines }\end{array}$} & \multirow[b]{2}{*}{$\begin{array}{l}\text { Non-arboreal } \\
\text { species that } \\
\text { dominate the } \\
\text { crown of trees, } \\
\text { especially the } \\
\text { upper and } \\
\text { middle thirds }\end{array}$} & \multirow[b]{2}{*}{$\begin{array}{l}\text { In degraded areas, the presence of } \\
\text { vines and lianas is more frequent } \\
\text { indicating the occurrence of } \\
\text { clearings in the area }\end{array}$} & Absent $=3$ \\
\hline & & & & Present $=1$ \\
\hline \multirow{8}{*}{ 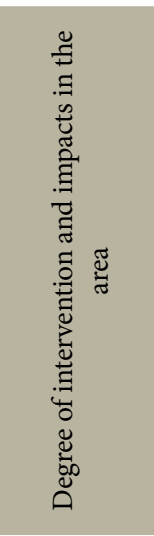 } & \multirow[b]{2}{*}{$\begin{array}{l}\text { Level of } \\
\text { disturbance } \\
\text { in the area }\end{array}$} & \multirow{2}{*}{$\begin{array}{l}\text { Occurrence of } \\
\text { fire, domestic } \\
\text { animals grazing, } \\
\text { garbage, artifacts } \\
\text { of woody } \\
\text { individuals }\end{array}$} & \multirow[b]{2}{*}{$\begin{array}{l}\text { The absence of disturbances } \\
\text { that restrict the development } \\
\text { and establishment of natural } \\
\text { regeneration and vegetation in } \\
\text { general }\end{array}$} & Absent $=3$ \\
\hline & & & & Present $=1$ \\
\hline & Human & & & Absent $=3$ \\
\hline & $\begin{array}{l}\text { presence } \\
\text { (negative } \\
\text { aspects) }\end{array}$ & Tracks and paths & $\begin{array}{l}\text { Disturbed areas frequently used by } \\
\text { people tend to become vulnerable } \\
\text { and may interfere with vegetation }\end{array}$ & Present $=1$ \\
\hline & \multirow{4}{*}{$\begin{array}{l}\% \text { of soil } \\
\text { cover with } \\
\text { grasses }\end{array}$} & \multirow{4}{*}{$\begin{array}{l}\text { Soil surface } \\
\text { covered by } \\
\text { invasive grasses }\end{array}$} & \multirow{4}{*}{$\begin{array}{c}\text { Dominant invasive species in } \\
\text { degraded areas indicate lack of } \\
\text { management control and cultural } \\
\text { practices }\end{array}$} & $0 \%=3$ \\
\hline & & & & $0 \%-25 \%=2$ \\
\hline & & & & $25 \%-50 \%=1$ \\
\hline & & & & $>50 \%=0$ \\
\hline \multirow{4}{*}{ 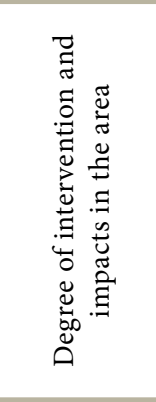 } & $\begin{array}{l}\text { Presence } \\
\text { of exotic } \\
\text { species }\end{array}$ & $\begin{array}{l}\text { Agricultural or } \\
\text { forest species } \\
\text { exotic to the } \\
\text { region and } \\
\text { invasive (except } \\
\text { for grasses) }\end{array}$ & $\begin{array}{c}\text { Absent in conservation areas or } \\
\text { used for environmental restoration } \\
\text { purposes }\end{array}$ & Absent $=3$ \\
\hline & \multirow{3}{*}{$\begin{array}{l}\% \text { area with } \\
\text { mulch }\end{array}$} & \multirow{3}{*}{$\begin{array}{l}\text { Ground } \\
\text { covered due } \\
\text { to silvicultural } \\
\text { practice on } \\
\text { grasses control. }\end{array}$} & \multirow{3}{*}{$\begin{array}{l}\text { The presence of mulch originated } \\
\text { from the control of grasses protects } \\
\text { the soil against erosion and favors } \\
\text { the penetration of water in the soil }\end{array}$} & $>50 \%=3$ (high) \\
\hline & & & & $30 \%-50 \%=2($ mean $)$ \\
\hline & & & & $0 \%-30 \%=1($ low $)$ \\
\hline \multirow{7}{*}{ 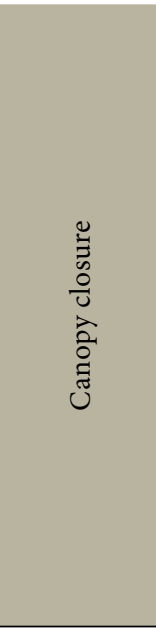 } & & & \multirow{3}{*}{$\begin{array}{l}\text { The rapid vegetation development } \\
\text { promotes shading in restoration } \\
\text { projects, reduces the incident } \\
\text { lightness on the soil, an important } \\
\text { factor on the weed-competition } \\
\text { reduction }\end{array}$} & $0 \%-30 \%=3($ low $)$ \\
\hline & $\begin{array}{l}\% \text { light on } \\
\text { the ground }\end{array}$ & $\begin{array}{l}\text { Amount of light } \\
\text { that crosses } \\
\text { the canopy and } \\
\text { reaches the } \\
\text { surface of the soil }\end{array}$ & & $30 \%-50 \%=2($ mean $)$ \\
\hline & $\begin{array}{l}\% \text { light at } \\
1 \mathrm{~m} \text { from the } \\
\text { ground }\end{array}$ & $\begin{array}{l}\text { Amount of light } \\
\text { reaching } 1 \mathrm{~m} \\
\text { from the ground }\end{array}$ & & $>50 \%=1$ (high) \\
\hline & \multirow{4}{*}{ Crown cover } & \multirow{4}{*}{$\begin{array}{l}\text { Canopy closure, } \\
\text { light reduction } \\
\text { and direct } \\
\text { incident rain on } \\
\text { the ground }\end{array}$} & \multirow{4}{*}{$\begin{array}{l}\text { The crown cover controls the } \\
\text { quantity, quality and temporal } \\
\text { and spatial distribution of light, to } \\
\text { determine differentiated levels of } \\
\text { air humidity, temperature and soil } \\
\text { moisture conditions (Halpern \& } \\
\text { Lutz, 2013) }\end{array}$} & $>50 \%=3$ \\
\hline & & & & $25 \%-50 \%=2$ \\
\hline & & & & $0 \%-25 \%=1$ \\
\hline & & & & $0 \%=0$ \\
\hline
\end{tabular}




\section{RESULTS AND DISCUSSION}

The highest similarity on species composition occurred for R, with 10 species in common with the others, while AR1 showed only one in common with AR2 (Table 3). Despite this, AR2 obtained the same AR1 values at $64.3 \%(n=9)$ of the system stability and resilience indicators (Figure 1).

Although AR1 presented higher diversity $\left(\mathrm{H}^{\prime}=1.671\right.$ nat.ind $\left.^{-1}\right)$ than AR2 $\left(\mathrm{H}^{\prime}=1.368\right.$ nat.ind $\left.^{-1}\right)$, there was no significant difference between them related to plant density, and on diversity and species composition indicators (SR, J and H') $\left(c^{2}=0.09818 ; p>0.01\right)$.

However, both showed a lower diversity index than other seasonal forests areas in the state of São Paulo, which diversity ranges from 3.0 nat.ind $^{-1}$ to 3.45 nat.ind $^{-1}$ (Filho \& Santin, 2002). Furthermore, at 48 months, AR2 still showed low species richness ( $S R=39)$, absence of epiphytes and low herbaceous and regenerant cover and number of species lower than 80 sp.ha ${ }^{-1}$ (Table 3), as recommended by SMA no. 8 of January 31, 2008 (São Paulo, 2008a).

There was a high mortality level in AR2 (29\%) with only 1.213 ind.ha $^{-1}$, and after 48 months, it was below the minimum limit of 1.667 ind.ha $^{-1}$ recommended by the legislation (São Paulo, 2008a). However, the density of plants in AR2 at 48 months, resembled other areas with 36 months ranging from 1.240 ind.ha $^{-1}$ to 2.200 ind.ha $^{-1}$ (Melo et al., 2007).

Concerning height and diameter, AR1 and AR2 differed from each other $\left(c^{2}=26.48 ; p<0.01\right)$, which was expected due to their difference of age. However, according to Conama Resolution no. 1 of January 31, 1994 (Brasil, 1994), both can be considered as initial

Table 3. Species diversity and density data; values obtained for the stability and resilience system attributes; as well as management and conservation of the studied areas. Data collected in 2012.

\begin{tabular}{|c|c|c|c|c|c|c|}
\hline Descriptor & Indicator & AR 1 & AR2 & $\mathbf{F}$ & $\mathbf{H}$ & $\mathbf{R}$ \\
\hline \multirow{4}{*}{$\begin{array}{l}\text { Diversity } \\
\text { and species } \\
\text { composition }\end{array}$} & Density (ind $\mathrm{hA}^{-1}$ ) & 1.720 & 1.213 & 1.420 & 1.380 & 980 \\
\hline & $\mathrm{H}^{\prime}$ (nat ind..$^{-1}$ ) & 1.671 & 1.368 & 1.3456 & 1.5003 & 1.2683 \\
\hline & $J^{\prime}$ & 0.8549 & 0.8599 & 0.3919 & 0.4067 & 0.4045 \\
\hline & SR & 91 & 39 & 31 & 40 & 23 \\
\hline \multirow{2}{*}{$\begin{array}{l}\text { Area } 1 \\
\text { structure }\end{array}$} & Height (m) & $7.7 \pm 3.05$ & $2.7 \pm 1.2$ & $3.9 \pm 0.5$ & $3.8 \pm 0.4$ & $3.9 \pm 0.7$ \\
\hline & $\mathrm{DBH}(\mathrm{cm})$ & $12.3 \pm 6.5$ & $4.0 \pm 0.9$ & $9.16 \pm 2.5$ & $9.90 \pm 1.5$ & $8.22 \pm 2.8$ \\
\hline \multirow{3}{*}{$\begin{array}{l}\text { Succession } \\
\text { process }\end{array}$} & Epiphytes & Presence & Absence & Absence & Absence & Absence \\
\hline & $\begin{array}{c}\text { Soil cover }(\%) \text { with herbaceous and } \\
\text { regenerating }\end{array}$ & $<25$ & $<25$ & 3.8 & 0 & 2.7 \\
\hline & Species by ecological group (\%) & 64.5 & 53.5 & 33.3 & 39.5 & 39.1 \\
\hline $\begin{array}{l}\text { Nutrients } \\
\text { contribution }\end{array}$ & Area covered by litter (\%) & $>75$ & $25-50$ & 7.0 & 11.3 & 3.8 \\
\hline Sanity & Termites and ants & Absence & Presence & Presence & Presence & Presence \\
\hline \multirow{5}{*}{$\begin{array}{l}\text { Intervention } \\
\text { degree and } \\
\text { impacts in the } \\
\text { area }\end{array}$} & Level of disturbance in the area & Absence & Absence & Presence & Presence & Presence \\
\hline & Human presence (negative aspects) & Presence & Absence & Presence & Presence & Absence \\
\hline & Soil cover with grasses (\%) & 25 & 50 & 53.8 & 42.1 & 34.5 \\
\hline & Presence of exotic species & Presence & Presence & Absence & Presence & Absence \\
\hline & Mulch (\%) & $<30 \%$ & $>50 \%$ & $<30 \%$ & $<30 \%$ & $>50 \%$ \\
\hline \multirow{3}{*}{$\begin{array}{l}\text { Canopy } \\
\text { closure }\end{array}$} & Light on ground (\%) & $>50$ & $>50$ & 20.9 & 30.8 & 32.4 \\
\hline & Light at $1 \mathrm{~m}$ from the ground (\%) & $>50$ & $>50$ & 23.7 & 34.3 & 32.4 \\
\hline & Crown cover $(\%)$ & $>50$ & $>50$ & 126.4 & 93.4 & 70.0 \\
\hline
\end{tabular}

AR1: conservation reference area in Sorocaba, SP; AR2: restoration reference area in Itu -SP; F: agroforestry system with forest species and pigeon pea, at 48 months (Porto Feliz, SP); H: agroforestry system with forest species and vegetable cultivation, at 48 months (Porto Feliz-SP); R: forest restoration at 60 months (Porto Feliz-SP); Ind.: individual; SR: number of tree species; J': Pielou index; H': Shannon index; DBH: Height and diameter deviation mean at breast height. 

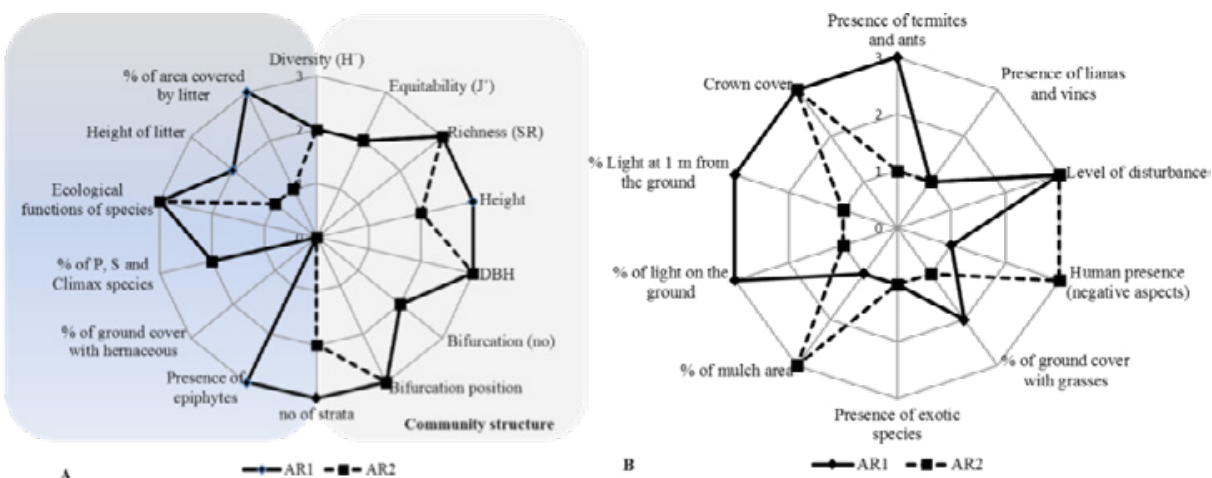

A
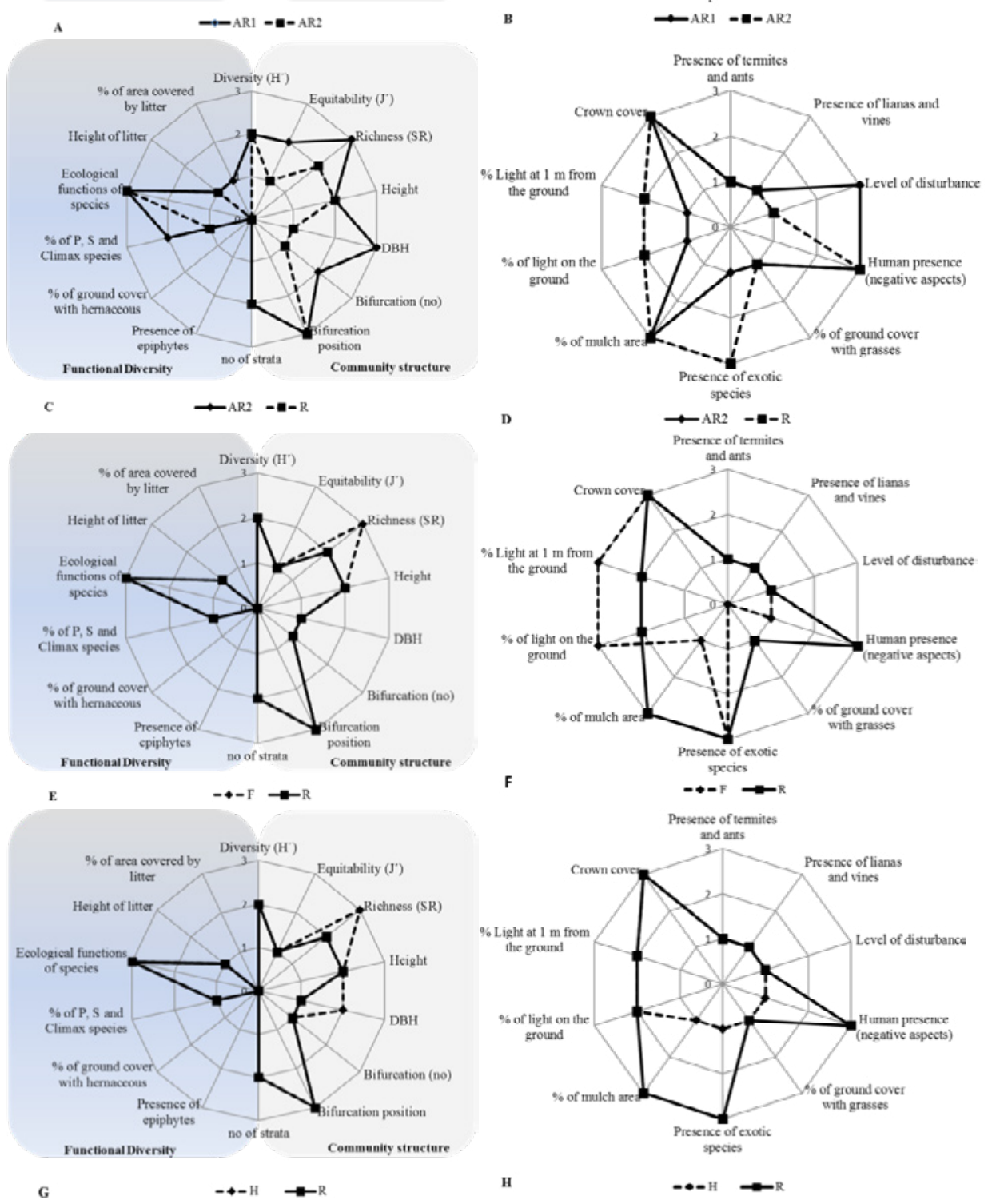

Figure 1. Values assigned to sustainability indicators for stability and resilience attributes (A, C, E, G) and management and conservation (B, D, F, H). AR1: conservation reference area; AR2: restoration reference area; R: forest restoration; F: agroforestry system with forest species and pigeon pea; $\mathrm{H}$ : agroforestry system with forest species and vegetables crops; P: pioneer species; S: secondary species; SR: number of tree species; H': Shannon index; J': Pielou index; DBH: height and diameter deviation mean at breast height. 
secondary forest, although considering the management and conservation attribute, AR2 presented $60 \%$ of the indicators $(\mathrm{n}=10)$ similar or higher than AR1. The presence of grasses in both AR1 and AR2 reflects the fact that canopy closure has not yet occurred, confirming its initial successional stage condition (Table 3, Figure 1B).

Comparing the two restoration areas (Figure 1C), it was observed that $\mathrm{R}$ was lower than AR2 in most of the community structure indicators (Table 3, Figure 1C). Regarding the system functional diversity, $66.7 \%$ of the indicators $(n=6)$ were the same and according to the management and conservation (Figure 1D), the $\mathrm{R}$ and AR2 areas were similar in $60 \%$ of the indicators $(\mathrm{n}=10)$.

Although AR2 is more recent than R, 48 and 60 months respectively, the AR2 best performance for stability and resilience may be a reflection of its community structure (Figure 1C). On the other hand, although AR2 received weeding four times a year and replanting in the 2nd year (Table 2), the R model with silvicultural management and practices at irregular intervals still showed higher soil covering indicators than AR2 (Figure 1D).

In the systems located in the same region, the $\mathrm{F}$ and R similarity for most ( $93 \%$ ) of stability and resilience indicators $(n=14)$ can be observed, except for species composition, in which $\mathrm{F}$ was higher than $\mathrm{R}$ (Figure 1E). Although the 31 species of $F$ represented only one third of the 80 species required by the legislation at that time (São Paulo, 2008a), this value was close to the 30 species recommended by SMA no. 44/2008 (São Paulo, 2008b) for AFSs (Table 3). Moreover, F also complies with this legislation in terms of number of individuals, with density above 1.000 ind.ha $^{-1}$. However, it was expected that in $\mathrm{F}$, the association with legumes species would provide greater organic matter input; however, there was no difference on soil litter height and covering between the two areas, with $50 \%$ of similarity among management indicators for $\mathrm{F}$ and $\mathrm{R}$ (Figures 1E and 1F).

Considering the $\mathrm{H}$ and $\mathrm{R}$ areas analysis, there was equality in $72 \%$ of the resilience stability indicators. This condition was lower than that observed for $\mathrm{F}$ and $\mathrm{R}$, which may represent a better restoration condition in the F model adoption. Despite this, $\mathrm{H}$ was similar to restoration (R) in $75 \%$ of the community structure indicators, being similar for functional diversity. In general, $\mathrm{H}$ was better than $\mathrm{R}$ only in the initial species composition and in DBH (Figure 1G), while they were similar in $60 \%$ of management and conservation indicators (Figure 1H).

Concerning restoration ecology, one of the possible objectives is the area return to the closest possible conditions of the original situation (Hobbs et al., 2009). The indicators showed that AR2 was different from the fragment (AR1) (Figure 2). In general, AR2 differed from AR1 towards the structure and successional processes, which can be attributed to their difference of age (Figures $1 \mathrm{~A}$ and $1 \mathrm{~B})$. However, the other restoration area $(\mathrm{R})$ was distinct from these areas and from the agroforestry systems $\mathrm{F}$ and $\mathrm{H}$ (Figure 2).

Although the two restoration areas were installed in the same model, $\mathrm{R}$ presented superior management results, but with structure indicators lower than AR2, showing low species and functional diversity (Figures $1 \mathrm{C}$ and $1 \mathrm{D})$. Even though these areas are only between 48 (AR2) and 60 months old (R), these data point out that the AR2 structure, rather than its management, mav have influenced the differences hetween them

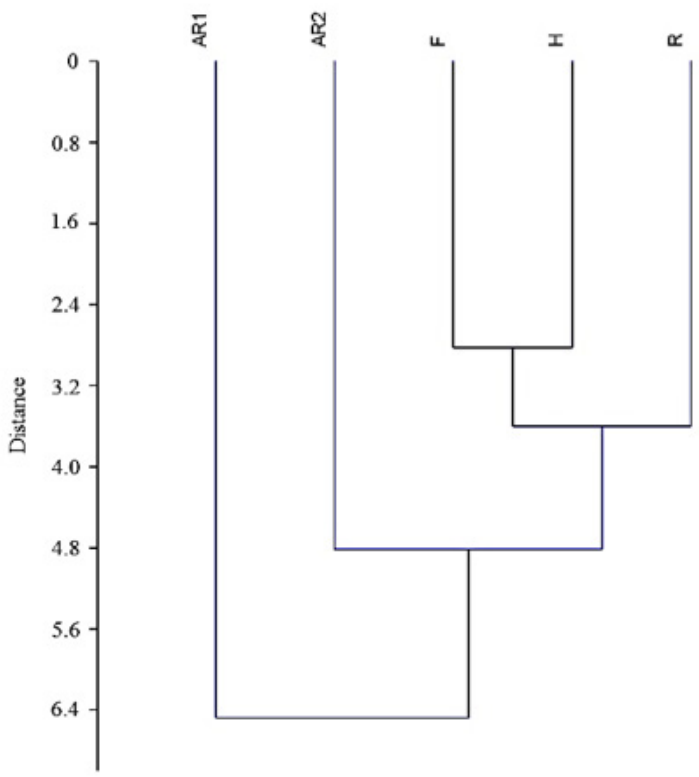

Figure 2. Grouping dendrogram areas based on indicators assessed. Sorocaba river basin and middle Tietê River, 2012. AR1: conservation reference area; AR2: restoration reference area; $\mathrm{F}$ : agroforestry system with forest species and pigeon pea; $\mathrm{H}$ : agroforestry system with forest species and cultivation of vegetables; $R$ : forest restoration. 
It can be suggested that, even with species richness increasing from 23, as observed in R, to 39 (AR2), or even 40 as in $\mathrm{H}$ (Table 3), this condition may not be sufficient to achieve the stability and the resilience observed in the fragments (AR1). The obtained data show that the low functional and the species diversity may have affected the restoration of the ecological functions and that, in this period, the number of species used was not enough to reach stability and resilience.

In terms of management, it is important to note that SMA Resolutions no. 08/2008 and SMA no. 44/2008 (São Paulo, 2008a, 2008b) recommended that AFSs could be managed only up to three years after planting. By the set of indicators, it can be affirmed that the two AFSs ( $\mathrm{F}$ and $\mathrm{H}$ ) did not provide, until 48 months, similar ecological conditions to the restoration plantings ( $R$ and AR2) and still less to the reference fragment (AR1). This reinforces the necessity to carry out adaptive management practices, specifically the enrichment with other species, even after 48 months. From 2014, this condition was incorporated into SMA Resolution no. 32/2014, which replaced SMA no. 08/2008 (São Paulo, 2008a, 2014).

The data obtained strengthen the need to review not only the legal guidelines on restoration, but also the methodology used. Observing the legal terms, SMA Resolution no. 32/2014 incorporated the need for monitoring based on ecological indicators. According to the indicators in this resolution, the studied area (R), even at 60 months, still falls into the category of "criticism" due to the low soil covering with native vegetation, the low number of native regenerating species and to the density of regenerants, requiring intervention.

At the same time, regarding the biomass contribution, litter production presented a higher value for AR1, which produced $6,898.32 \mathrm{~kg} \mathrm{ha}^{-1}$ year $^{-1}$. Among the analyzed models, the highest contribution was obtained from $\mathrm{H}$ with production of $3,189.85 \mathrm{~kg} \mathrm{ha}^{-1}$ year ${ }^{-1}$. The model F presented $2,430.32 \mathrm{~kg} \mathrm{ha}^{-1}$ year $^{-1}$ and $\mathrm{R}, 1,856.78 \mathrm{~kg} \mathrm{ha}^{-1}$ year $^{-1}$. Despite the contribution promoted, only $\mathrm{H}$ presented similar values to those from dry forests in the same region with $3.3 \mathrm{tha}^{-1}$ year $^{-1}$ to 8.0 t ha $^{-1}$ year $^{-1}$ (Scoriza \& Piña-Rodrigues, 2014) and those from other models of AFSs in legally protected riparian areas in the Atlantic Forest (Souza et al., 2016).
Table 4. Density, estimated carbon stock values, annual average increment (AAI) of carbon stock in living aboveground biomass for restoration and agroforestry systems in Porto Feliz, SP, 2012.

\begin{tabular}{ccccc} 
Area & $\begin{array}{c}\text { Density } \\
\left(\text { trees ha }^{-1}\right)\end{array}$ & $\begin{array}{c}\text { Age } \\
\left(\text { months }^{\prime}\right)\end{array}$ & $\begin{array}{c}\text { Carbon } \\
\left(\mathbf{t ~ h a}^{-1}\right)\end{array}$ & $\begin{array}{c}\text { Carbon AAI } \\
\left(\mathbf{t ~ h a ~}^{-1} \text { year }^{-1}\right)\end{array}$ \\
\hline R & 980 & 60 & 17.91 & 3.58 \\
F & 1420 & 48 & 34.09 & 8.52 \\
H & 1380 & 48 & 39.81 & 9.95 \\
\hline
\end{tabular}

$\mathrm{R}$ : forest restoration; F: agroforestry system with forest species and pigeon pea; $\mathrm{H}$ : agroforestry system with forest species and vegetables crops.

Regarding the fixation of atmospheric carbon, $\mathrm{H}$ and F (Table 4) were superior to the 1-to-6-year plantations from the Paranapanema Valley, whose values ranged from $1.07 \mathrm{t} \mathrm{ha}^{-1}$ to $19.7 \mathrm{t} \mathrm{ha}^{-1}$ (Melo \& Durigan, 2006). Although the indicators have shown less efficiency in the restoration of ecological functions, AFSs models have accumulated carbon in a greater proportion than the restoration $(R)$, showing their potential in providing environmental services, regarding this parameter.

\section{CONCLUSIONS}

Up to 48 months, the agroforestry systems models studied did not promote the ecological functions restoration when compared to restoration areas, but were superior in terms of carbon fixing, especially in the sequential association of forest and short-cycle agriculture. The species diversity and the functional diversity were more important than management for the ecological restoration functions; however, the 48 months management was insufficient to allow the reestablishment of the expected ecological functions.

\section{SUBMISSION STATUS}

Received: 2 Aug., 2017

Accepted: 22 Dec., 2017

\section{CORRESPONDENCE TO}

\section{Lucas Bertacini Viégas}

Universidade Estadual Paulista Júlio de Mesquita Filho, Rua José Barbosa de Barros, 1.780, CEP 18610-307, Botucatu, SP, Brasil e-mail: lucasbertacini@yahoo.com.br 


\section{REFERENCES}

Astier M, Speelman EN, López-Ridaura S, Masera OR, González-Esquivel CE. Sustainability indicators, alternative strategies and trade-offs in peasant agroecosystems: analyzing 15 case studies from Latin America. International Journal of Agricultural Sustainability 2011; 9(3): 409-422. 10.1080/14735903.2011.583481

Brasil. Resolução Conama n. 1, de 31 de janeiro de 1994. Diário Oficial da República Federativa do Brasil, Brasília, DF (1994 Feb 3); Sec 1: 1684-1685.

Brasil. Resolução Conama n. 429, de 28 de fevereiro de 2011. Diário Oficial da República Federativa do Brasil, Brasília, DF (2011 Mar 2): 76.

Brasil. Decreto n. 8.952, de 9 de janeiro de 2017. Diário Oficial da República Federativa do Brasil, Brasília, DF (2017 Jan 24).

Brown S. Estimating biomass and biomass changing of tropical forests: a primer. Rome: FAO Forestry Paper; 1997.

Deponti CM, Eckert C, Azambuja JLB. Estratégia para construção de indicadores para avaliação da sustentabilidade e monitoramento de sistemas. Agroecologia e Desenvolvimento Rural Sustentável 2002; 3(4): 44-52.

Filho RC, Santin DA. Estudo florístico e fitossociológico de um fragmento florestal urbano - Bosque dos Alemães, Campinas, SP. Revista Brasileira de Botânica 2002; 25(3): 291-301. 10.1590/S0100-84042002000300005

Fundação de Estudos e Pesquisas Aquáticas - Fundespa. Plano diretor Ambiental de Porto Feliz, SP. São Paulo; 2009.

Fundação Instituto de Terras do Estado de São Paulo Itesp. Relatório técnico de avaliação do potencial da área do projeto de assentamento de Porto Feliz. Sorocaba: Itesp; 2007.

Halpern CB, Lutz JA. Canopy closure exerts weak controls on understory dynamics: a 30-year study of overstoryunderstory interactions. Ecological Monographs 2013; 83(2): 221-237. 10.1890/12-1696.1

Hammer O, Harper DAT, Ryan PD. Past: Paleontological Statistics Software Pack-age for Education and Data Analysis. Paleontologia Electronica 2001; 4(1): 1-9.

Hobbs RJ, Higgs E, Harris JA. Novel ecosystems: implications for conservation and restoration. Trends in Ecology and Evolution 2009; 24(11): 599-605. 10.1016/j. tree.2009.05.012

Lomov B, Keith DA, Britton DR, Hochuli DF. Are butterflies and moths useful indicators for restoration monitoring? A pilot study in Sydney's Cumberland Plain Woodland. Ecological Management and Restoration 2006; 7(3); 204-210. 10.1111/j.1442-8903.2006.00310.x

López-Ridaura S, Masera O, Astier M. Evaluating the sustainability of complex socio-environmental systems: the Mesmis framework. Ecological Indicators 2002; 2(1-2): 135-148. 10.1016/S1470-160X(02)00043-2

MacDicken KG. A guide to monitoring carbon storage in forestry and agroforestry projects. Arlington: Winrock International Institute for Agricultural Development; 1997.

Magurran AE. Measuring biological diversity. Oxford: Blackwell; 2004.

Melo ACG, Durigan G. Fixação de carbono em reflorestamentos de matas ciliares no Vale do Paranapanema, SP, Brasil. Scientia Forestalis 2006; 71(50): 149-154.

Melo ACG, Miranda DLC, Durigan G. Cobertura de copas como indicador de desenvolvimento estrutural de reflorestamentos de restauração de matas ciliares no Médio Vale do Paranapanema, SP, Brasil. Árvore 2007; 31(2): 321-328. 10.1590/S0100-67622007000200015

Nair PKR. Carbon sequestration studies in agroforestry systems: a reality-check. Agroforestry Systems 2012; 86(2): 243-253. 10.1007/s10457-011-9434-Z

Oliveira VR, Silva PSL, Paiva HN, Pontes FST, Antonio RP. Growth of arboreal leguminous plants and maize yield in agroforestry systems. Árvore 2016; 40(4): 679-688. 10.1590/0100-67622016000400011

Piotto D. A meta-analysis comparing tree growth in monocultures and mixed plantations. Forest Ecology and Management 2008; 255(3-4): 781-786. 10.1016/j. foreco.2007.09.065

Ricarte JD, Ribeiro MT, Fagundes GG, Ferraz JMG, Habib M. Avaliação de agroecossistemas em propriedades de produção orgânica no município de Jaguariúna/SP através de indicadores de sustentabilidade. Interagir Pensando a Extensão 2006; 9: 173-184.

Rodrigues RR, Brancalion PHS, Isernhagen I (org.). Pacto pela restauração da Mata Atlântica: referencial dos conceitos $e$ ações de restauração florestal. 3. ed. São Paulo: LERF/ ESALQ; 2009.

São Paulo. Secretaria do Meio Ambiente. Resolução n. 8, de 30 de janeiro de 2008. Diário Oficial do Estado de São Paulo, São Paulo, (2008a); Sec. 88/07: 196.

São Paulo. Secretaria do Meio Ambiente. Resolução SMA n. 44, de 30 de junho de 2008. Diário Oficial do Poder Executivo, São Paulo (2008b Jun 2); Sec 1: 45.

São Paulo. Secretaria do Meio Ambiente. Resolução SMA n. 32, de 3 de abril de 2014. Diário Oficial do Poder Executivo, São Paulo (2014 Apr 5); Sec 1: 36-37.

Scoriza RN, Piña-Rodrigues FCM. Influência da precipitação e temperatura do ar na produção de serapilheira em trecho de Floresta estacional em Sorocaba, SP. Floresta 2014; 44(4): 687-696. 10.5380/rf.v44i4.34274

Seoane CE, Froufe LC, Amaral-Silva J, Arantes ACV, Nogueira R, Steenbock W. Conservação ambiental forte alcançada através de sistemas agroflorestais 
multiestratificados: 1 agroflorestas e a restauração ecológica de florestas. Cadernos de Agroecologia 2014; 9(4): 1-11.

Sharrow SH, Ismail S. Carbon and nitrogen storage in agroforests, tree plantations and pastures in western Oregon, USA. Agroforestry Systems 2004; 60(2): 123-130. 10.1023/B:AGFO.0000013267.87896.41

Souza MCS, Piña-Rodrigues FCM, Casagrande JC, Silva SF, Scoriza RF. Funcionalidade ecológica de sistemas agroflorestais biodiversos: uso de serapilheira como indicador da recuperação de áreas de preservação permanente. Floresta 2016; 46(1): 75-82. 10.5380/rf.v46i1.34991
Srivastava DS, Vellend M. Biodiversity-ecosystem function research: is it relevant to conservation? Annual Review of Ecology, Evolution and Systematics 2005; 36: 267-294. 10.1146/annurev.ecolsys.36.102003.152636

Theodoro VCA, Castro FP, Aburaya FH. Indicadores ecológicos de sustentabilidade de unidades de produção agrícola do assentamento Facão - Cáceres, MT, Brasil. Revista Brasileira de Agroecologia 2011; 6(3): 21-33.

Tongway DJ, Hindley NL. Landscape function analysis: procedures for monitoring and assessing landscapes. Canberra: CSIRO; 2004. 